\title{
How Fiscal Policy Affects Prices: Britain's First Experience with Paper Money
}

Pamfili M. Antipa

For almost 25 years between 1797 and 1821, the gold standard in Britain was suspended in order to finance the Napoleonic Wars, creating a paper pound or a fiat currency. Suspension was accompanied by substantial inflation and the accumulation of public debt. By identifying shifts in the spot exchange rate of paper pounds for gold, I document how contemporaries' expectations of how debt would be stabilized in the future shaped the pound's internal value. Thus, it is argued that during the "paper pound" period, fiscal prospects provided a third mechanism, beyond monetary and real factors, affecting the price level.

$\mathrm{B}$ etween 1797 and 1821, in order to finance the Napoleonic Wars, Britain suspended convertibility of Bank of England notes into gold. Earlier suspensions, such as 1696/97, during the Great Recoinage and 1745 for the Jacobite rising, had been short-lived. Thus, in terms of monetary policy maintaining the suspension of the gold standard for such a long period of time was an innovation. However, funding of the wars with France meant that the suspension was accompanied by inflation and public debt accumulation. By the time of Napoleon's final defeat at Waterloo in 1815, the price level exceeded its 1797 level by 22.3 percent (Gayer, Rostow, and Schwartz 1953) and the debt-to-GDP ratio climbed to 226 percent; as shown in Figure 1, only WWI would entail a larger increase in the debt-to-GDP ratio (Officer and Williamson 2013).

The Journal of Economic History, Vol. 76, No. 4 (December 2016). (C) The Economic History Association. All rights reserved. doi: 10.1017/S0022050716000978

Pamfili Marina Antipa is Research Economist at Banque de France, 31 rue Croix des Petits Champs, Paris 75001, France. E-mail: pamfili.antipa@banque-france.fr, pmantipa@yahoo.de.

The views expressed herein are those of the author and do not necessarily reflect those of the Banque de France. I am particularly indebted to Olivier Accominotti, Vincent Bignon, Christophe Chamley, Pierre-Cyrille Hautcoeur, Larry Neal, Patrick O’Brien, Kim Oosterlinck, Eugene White, and two anonymous referees and Ann Carlos, the editor of this JournaL. I also thank Arie Arnon, Robert Barsky, Jean Barthelemy, Michael Bordo, Stephen Broadberry, Rui Esteves, Sophie Guilloux-Nefussi, Christian Hellwig, Andrew Jalil, Julien Matheron, Christopher Meissner, Eric Mengus, Pierre-Guillaume Méon, Sarah Mouabbi, Nuno Palma, Xavier Ragot, Annukka Ristiniemi, Albrecht Ritschl, Hugh Rockoff, Pierre Sicsic, André Strauss, and François Velde for helpful comments. Comments from participants at the 2013 European Historical Economics Society Conference, the 2014 Economic History Society Conference, the Beta Workshop in Historical Economics, the 2014 Economic History Association Meeting, the 2015 EABH Workshop for New Scholars in Financial History, and the 2015 Workshop on Monetary and Financial History at the Federal Reserve Bank of Atlanta, and Emory University are gratefully acknowledged. 


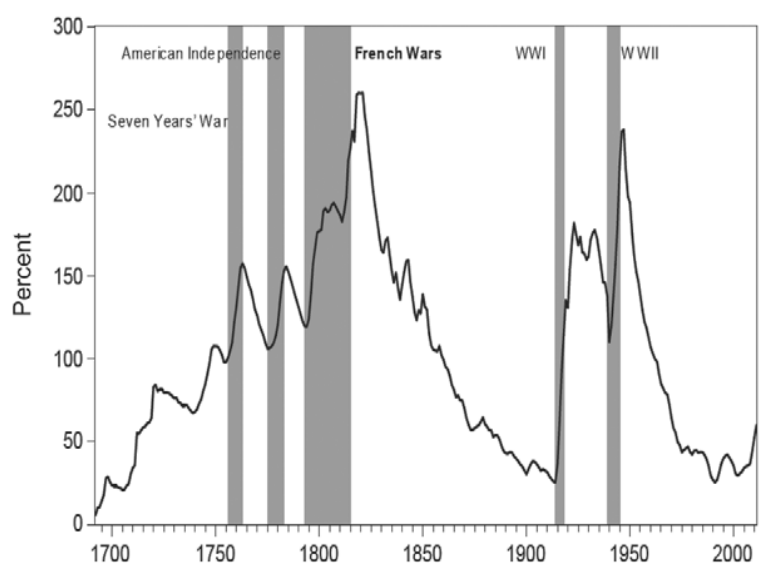

FIGURE 1

DEBT-TO-GDP RATIO, 1692-2011

Sources: Mitchell 1988; Officer and Williamson 2013.

The Restriction Period (1797-1821) is crucial for an understanding of the history of British institutions and price history. Starting with the suspension, a long-standing debate has attributed the evolution of prices during the "paper pound" period to either real or monetary factors. Thomas Tooke (1824), an eminent political economist, and the Bank of England administration articulated the Real Bills doctrine arguing that the Bank's note issue could not be inflationary since it was undertaken against sound commercial bills. Rather bad harvests, the war, and trade blockades induced higher domestic prices, while the outflow of funds used to pay for food imports and to subsidize British allies on the continent caused the external devaluation of the pound. For David Ricardo (1817) and advocates of the bullionist position, it was the issue of Bank of England notes themselves that primarily affected prices, as reflected in the paper pound's gold value in the market. ${ }^{1}$

In this article, I propose a novel, third explanation: expectations of how debt would be stabilized post war determined the pound's exchange rate into gold. Such expectations would also determine the Greenback's gold price during the much shorter American Civil War (Calomiris 1988; Guinnane, Rosen, and Willard 1996). Given substantial debt accumulation and inflation, returning to the pound's pre-war gold content would come at high deflationary cost: wartime inflation had to be undone by peacetime deflation. Another option - namely, getting back to the gold standard at

\footnotetext{
${ }^{1}$ More recently, Bordo and Schwartz (1981) re-emphasized the importance of monetary factors for price level determination vis-á-vis Lewis (1978) and Rostow (1948).
} 
a devalued pound - was by no means precluded (Acworth 1925; Fetter 1965; Kindleberger 2000). Not only would devaluation have spared the war-ridden economy from deflation and its impacts on economic activity, but by decreasing the purchasing power of the pound, it would also have alleviated the burden of outstanding debt. Some contemporaries were even concerned with the possibility that cash payments would never be resumed, as uttered by Bank proprietors when the suspension of convertibility was reiterated for the first time after hostilities had ceased in the spring of 1816 (London Times 13 April 1816).

Contemporaries understood this trade-off between the nominal value of the pound and the real amount of outstanding government debt and could form expectations about fiscal prospects to gauge whether the future policy choice would induce deflation or inflation. The type of information that mattered for predicted fiscal sustainability related to war finance, with roughly two-thirds of Britain's budget dedicated to warfare (O'Brien 1988). ${ }^{2}$ Moreover, apart from being a costly endeavor, war could, in the worst outcome, render otherwise solid public finances unsustainable. For instance, severe territorial losses and the resulting impact on an economy's tax base or imminent reparation payments (Oosterlinck 2012) could push an economy to a point where devaluation-induced inflation would become inevitable. On the other hand, as British supremacy was in the making over the long conflict, so too was the credibility of certain promised policies - such as the resumption of the gold standard at the pre-war parity - that were to be enacted conditional on the outcome of the war.

How did contemporaries view the chances of returning to the pound's pre-war gold content? I quantify this using financial data that captures the expectations of economic agents as manifested in market prices (see Frenkel 1977; Webb 1986). In particular, I use a series, the agio, that is computed as the difference between the pound's official exchange rate into gold (the mint price) and its market exchange or spot rate, reflecting transactions undertaken instantaneously. ${ }^{3}$ The mint price carried the promise that pounds would be exchanged against gold at the pre-war parity at some unknown moment in the future, conditional on the conclusion of a definite peace treaty. As such, the mint price can be seen as the price of a forward contract on the pound. ${ }^{4}$ Differences between the two

\footnotetext{
${ }^{2}$ The same was true for most other European countries during that period (Hoffman 2011).

${ }^{3}$ The market price of gold was published twice a week in Castaing's and-later onWettenhall's Course of the Exchange. For contemporaries this was, therefore, easily available information.

${ }^{4}$ The mint price differs somewhat from a classic forward contract, as the obligation to exchange paper pounds against a pre-determined quantity of gold does not commence at a known date but is conditional on the materialization of a certain event.
} 
then were reflected in the discount factor that differentiated the value of a paper pound at time $t$ from its expected gold content in the future. The discount factor captured how risky and, by extension, how credible the promise of resuming the gold standard at its pre-war parity was in the eyes of contemporaries.

Switching from the gold standard to a fiat currency regime effectively replaced the risk of sovereign default with the risk of inflation (Calomiris and Haber 2014). Adjustments in the real value of outstanding debt could be engineered through devaluations of the currency. In other words, monetary regime choices and their operation shaped how people expected debt to be stabilized. Inflation risk, in turn, was equivalent to the expectation of not getting back to the pound's pre-war parity. The operation of the gold standard pinned down a nominal exchange rate of domestic paper money into gold. Such a system yielded a relatively stable price level in the long run, implying on average low growth rates of inflation (Barro 1979). ${ }^{5}$ The path of inflation during a suspension was, by the same token, affected by the exchange rate at which convertibility would be resumed and the expectations thereof. For the suspension period, a forecast of on average zero inflation in the long term was an accurate one, only if people were convinced that resumption at the pre-war parity was certain.

Significant changes in the agio, thus, convey information about events that caused contemporaries to alter their predictions on the future state of public finances and should be identifiable as structural breaks. I verify the importance of events, matched with detected break dates by considering contemporary sources and archival evidence. In particular, I consult the London Times, the London Gazette, the government's official journal, and ledgers from the Bank of England archives to establish links between observed price movements and the incidents that caused them. I find that significant changes in the agio coincided with events that prompted reassessment of Britain's expected military fate. In particular, with unfavorable news, of a battle lost, for example, the pound's internal value declined, as devaluation became more likely. With favorable news, the pound's purchasing power increased. As Britain's payment system during the suspension period rested on the paper pound, changes in the agio implied changes in the aggregate price level.

\footnotetext{
${ }^{5}$ The adjustment mechanism embedded in the gold standard requires that inflationary outbursts are countered by deflationary episodes. While this entails on average low rates of inflation, it also induces high short- to mid-term volatility in prices and activity (Meltzer and Robinson 1989).
} 


\section{THE ONSET OF CONVERTIBILITY SUSPENSION AND THE BULLION REPORT}

The French Wars, 22 years of almost uninterrupted warfare between 1793 and 1815, encompassed Europe's political reshuffling following the French Revolution and Britain's struggle against Revolutionary and later on Napoleonic France. France's drive to export revolutionary ideals soon drove the country to war with most of Europe. The execution of King Louis XVI in January of 1793 sealed the first coalition against France. ${ }^{6}$ It would take a total of seven differing coalitions between the Continental European powers and Britain to finally defeat Napoleon at Waterloo on 18 June 1815.

The wars exerted extreme political and financial pressures on all belligerents. The Reign of Terror in France, beginning in early 1793, produced a sharp outflow of capital, with silver and gold leaving France for Britain and providing increased liquidity for the British banking system (Neal 1991; Sargent and Velde 1995). When the assignats collapsed in France in 1795, money for ordinary payments was in short supply and those with claims or credit in Britain drew on them to fill the gap. The ensuing return flow of capital to France, by lowering the stock of precious metal, put deflationary pressure on Britain (Kindleberger 1984).

Against this backdrop, French military actions in February 1797 triggered bank runs in Britain with depositors hoping to convert notes into gold coin. The consequences were felt throughout the country, putting numerous (country) banks out of business (Feavearyear 1963). Eventually, the run reached the ultimate provider of specie and, thus, de facto center of the British payment system, the Bank of England. With gold reserves threatened, the Bank was given permission to cease payment of its notes in gold on the $27^{\text {th }}$ of February 1797 and suspension ensued.

With suspension, local bank notes were now convertible only into Bank of England notes, shifting Britain's monetary system from a commodity standard to a fiat currency with flexible exchange rates. Once the constraints imposed by the gold standard were abandoned, it became possible to accommodate the external drain of specie caused by Britain's expenditures on the Continent, and to grant the means of payment necessary for internal transactions, while absorbing increasing public debt issues (Bordo and White 1991). Britain now had a payment system in which the money supply was controlled by the Bank and the Treasury.

\footnotetext{
${ }^{6}$ Following the execution, Britain expelled the French ambassador and on 1 February France responded by declaring war on Great Britain.
} 
Conceived as an emergency measure, the suspension was regularized in November 1797 and extended several times. In December 1803, the Bank Restriction Act finally fixed its end at six months after the ratification of a definitive peace treaty. Over the 22 years of the French Wars, resumption of the gold standard was often a remote and uncertain prospect. Peace treaties proved to be inconclusive such as those of Amiens (in April 1802) and Paris (in June 1814). Even after the peace treaty of 1815, resumption was postponed several more times.

The years following 1797 saw the Second, Third, and Fourth Coalition Wars against France. France prevailed in military terms. Yet, Napoleon's attempt to undermine British trade by initiating the Continental Blockade (21 November 1806) remained unsuccessful especially given the defeat of the French fleet at Trafalgar (October 1805). This British victory also averted the danger of a French invasion. Hostilities intensified further when Napoleon initiated the Peninsular War to punish the Portuguese for not enacting the Continental System against the British. French and Spanish troops invaded Portugal in November 1807. Napoleon turned on his former ally by attacking Spain in February 1808. The year 1809 proved disastrous in military terms for the British, on all war fronts. Over the first quarter of the year, the French occupied northern Portugal and forced the British to evacuate Spain. In July, the Fifth Coalition of Austrian- and British-led forces was defeated at the battle of Wagram. By the end of the year, the French beat the remaining forces in the south of Spain; the area being taken in the following winter, leading to French control in most of the Iberian Peninsula. By 1810, French victory seemed possible.

During these years, the paper pound's exchange rates into gold and foreign currencies started depreciating. Figure 2 depicts both the agio and the pound's exchange rate on Hamburg. Before the suspension of the gold standard (shaded area) and even during the first years of the latter, both metrics fluctuated in relatively narrow bands: de- or appreciations of the paper pound hardly ever exceeded 10 percent. Beginning in 1809, the agio and the exchange rate experienced marked declines, peaking at 50 and 30 percent, respectively. Ex-post constructed price indices, shown in Figure 3, exhibited the same pattern. Both series increased substantially with the suspension and particularly after 1809 and declined-albeit more gradually - after the resumption of the gold standard in 1821 .

These changes in the agio and in prices prompted the government to appoint an investigating committee, which published its work in 1810 as the Bullion Report. According to the report, rising prices and falling exchange rates had a common source in the Bank of England issuing 


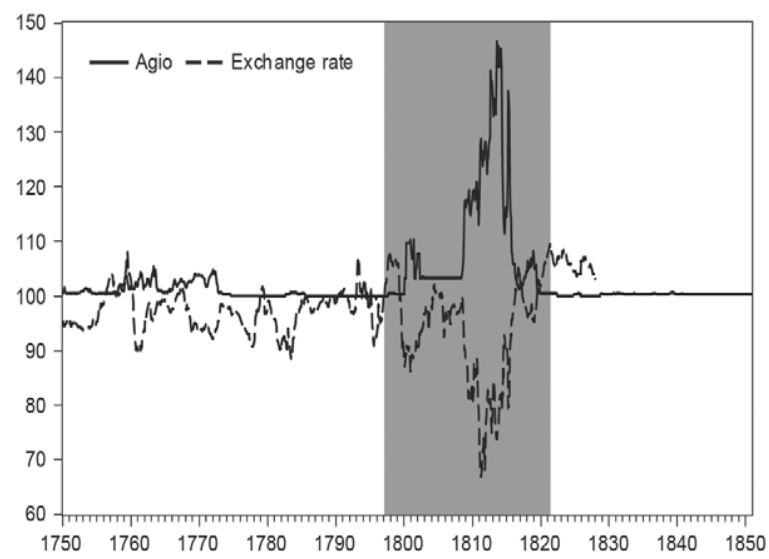

FIGURE 2

AGIO, 1750-1850; EXCHANGE RATE HAMBURG: SCHILLING PER POUND STERLING, TWO MONTHS' USANCE, 1750-1825. FOR BOTH INDICES JAN 1797=100

Notes: The shaded area marks the suspension of the gold standard from 1797 to May 1821.

Sources: Neal 1990; Boyer-Xambeu et al. 1994.

too many notes. ${ }^{7}$ Notes were issued to buy the government debt, which in turn was used to finance the Napoleonic Wars. This would have been impossible had the Bank of England retained its obligation to convert its liabilities into bullion.

The Bank of England had indeed expanded its note issue, but the peak was reached only when the bursting of the South American bubble in late 1810 caused widespread panic and business failures (Feavearyear 1963; O'Brien 2010). Amid spreading commercial distress, country banks started to contract their note issue drastically. The liquidity shortage was broadly acknowledged and the Treasury attempted to overcome it by issuing Exchequer Bills. Thus, at least part of its note issue could be accounted for by its normal function to sustain the domestic payment system, when other forms of credit were disappearing (O'Brien 2010; Clapham 1944; Flinn 1961).

The marked devaluation of the pound after 1809 coincided rather with the military misfortunes of the British than with the evolutions in the Bank's note issue. Moreover, with the intensification of hostilities around 1809 a turning point would also be attained in terms of public finance.

\footnotetext{
${ }^{7}$ Neal (1991) argues that the interruption of trade with the Continent caused the exchanges to fall. By implementing the Continental System, Napoleon consciously sought to undermine British war financing. In particular, by rendering it difficult to import British goods, Napoleon attempted to constrain corresponding capital flows from the Continent to Britain.
} 


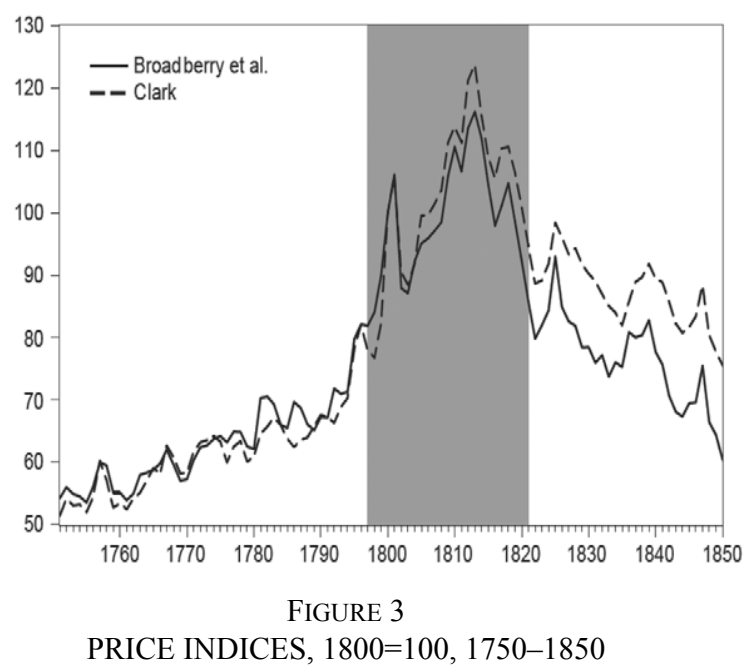

Notes: The shaded area marks the suspension of the gold standard from 1797 to May 1821. Sources: Broadberry et al. 2012; Clark 2014.

\section{FISCAL PRESSURE AND INTERACTIONS BETWEEN THE BANK AND THE TREASURY}

Institutional characteristics enabled Britain to mobilize war finance at an impressive scale and laid the basis for her military and commercial supremacy over most of Continental Europe (Brewer 1988). Parliament gained broad powers over public expenditures and taxation through the Glorious Revolution; loans to government and the taxes earmarked to service them necessitated parliamentary assent (Sussman and Yafeh 2006). Furthermore, the government created a separate sinking fund to cover the planned reimbursements in case revenues earmarked for specific loans proved insufficient (Cox 2015). Partisan politics further rendered outright default politically unacceptable (Stasavage 2007).

The Bank of England acted as an additional private constraint on the government. It was responsible for assuring the continuity of promised reimbursements. As such, it could have refused to grant new loans whenever arrears on existing ones occurred. Channeling all public credit through the Bank therefore implied that it would become difficult to utilize funds of current loans whenever previous obligations were not honored (Macaulay 1914; North and Weingast 1989). Thus, by the time the French Wars had to be financed, contemporaries dismissed the risk of strategic default, making large scale debt accumulation possible (Acworth 1925; Neal 1990; O’Brien 2010). 
Nonetheless, by 1809 , prolonged and intensified warfare had taken toll on public finances. Following the usual practice, expenditures during the first years of the war were paid for by issuing long-term government debt (Barro 1987). As a result the national debt had doubled during the first six years of unsuccessful warfare against Revolutionary France and large loans against bonds (funded debt) continued to be issued in every year of the war. ${ }^{8}$ Only in 1809 , considerable loans were floated for England, Ireland, and Portugal (Grellier 1812).

As much as debt finance was an essential part of war funding, it was backed by a strong increase in taxation, with tax receipts accounting for 58 percent of the extra revenues necessary to fund the wars (O'Brien 1988). ${ }^{9}$ Yet, by 1809 , the government had exhausted its possibilities for taxation. The introduction of the income tax in 1799 had only been possible given the highly exceptional circumstances. By February 1799, the price of consols had declined by 26 percent, to the lowest levels of the French Wars, reflecting grave doubts about the stability of public securities. The strength of opposition to the so-called "repugnant tax" was visible in its instant revocation upon the Peace of Amiens in 1802 and in 1816, shortly after the victory at Waterloo (O'Brien 1988).

For excise taxes, a broad social consensus argued that it was indecent to impose duties on the necessities or the poor; so mostly goods consumed by the affluent were further taxed. Between 1793 and 1815, two-thirds of the extra taxation required to finance the French Wars came from taxes levied on the incomes and consumption patterns of the wealthy and ${ }^{10}$ further increases in tax rates had become self-defeating (O'Brien 1988, 2007).

As a result, the Treasury had to rely heavily on the Bank for war finance. Short-term borrowing against Exchequer or Navy bills (unfunded debt) increased by 22 percent in 1809 (Mitchell 1988). Unfunded debt had the great advantage of not necessitating parliamentary assent and of not coming with earmarked taxes. ${ }^{11}$ It was, thus, often used to finance unforeseen expenditures (O'Brien 2007). As both manager and holder of public debt, the Bank of England became essential for financing the war effort.

The Bank could hardly refuse requests for credit from the Treasury in times of war, especially since the monopoly of issue it enjoyed in

\footnotetext{
${ }^{8}$ Report by the Secretary and Comptroller General of the Proceedings of the Commissioners for the Reduction of the National Debt, 1891.

${ }^{9}$ Income from seigniorage remained negligible (Bordo and White 1991).

${ }^{10}$ The remainder was mostly levied on two widely approved objects of taxation, namely alcohol and tobacco.

${ }^{11}$ As soon as Britain went to war in 1793, 33 Geo. III, c. 32 officially legalized the already usual practice of advancing funds for Exchequer bills without parliamentary authorization or funding, a practice not in compliance with the Bank's Foundation Act (5 and 6 William and Mary, c.10).
} 
the wider London area was subject to periodic renewal. With the Bank charter renegotiable at will, bargaining over renewals were often reached along with war loans, as was the case in 1781 and 1800 in the midst of the American and French Wars (Broz and Grossman 2004).

The Bank's interactions with the Treasury came with certain risks. During the Restriction Period, more than half of the Bank's assets were held in public securities; in the aftermath of the war, this rose to almost 70 percent. Holding substantial amounts of sovereign short-term debt on its balance sheet, the Bank's financial solidity depended on the Treasury's will to honor its running obligations.

War finance was, nonetheless, a very lucrative business for the Bank and its shareholders. Figure 4 displays the evolution of the Bank's stock price over the 25 years from January 1796 to December 1821. The monthly price index is set to 100 in January 1797, the month before the suspension, and deflated by the pound's value in gold. The stock price almost tripled between the suspension of convertibility (solid left line) and its peak in November 1817. Especially after the beginning of the Third Coalition War against France in May 1803 (dashed line) the stock price increased markedly. ${ }^{12}$

The Bank's stock price reflected changes in its expected cash flows to share-holders. As the latter hinged largely on the management of public credit, times of increasing debt - such as war times - were profitable for the Bank: beyond the interest the Treasury paid on the majority of loans with the Bank, the latter also charged management fees for handling the public debt. Billing $£ 450$ per million of public debt, the Bank’s income increased automatically when war debts soared. ${ }^{13}$

In June 1815 with the news of the victory at Waterloo, the Bank's income and stock price decreased; this was also the case with the decision to resume the gold standard in May 1819 (solid right line in Figure 4). Yet, these did not fall back to levels usual before the suspension of payments. Despite revised management fees and falling discounts, the sheer size of the public debt assured a comfortable level of revenue to the Bank. Parliament's refusal to maintain the income tax certainly helped

\footnotetext{
${ }^{12}$ The increase encompasses the years preceding the battle of Trafalgar (October 1805) at which the French fleet was defeated, averting the danger of French invasion. The absence of any sizable departures from the increasing trend in the stock price casts doubt on whether financial markets perceived the threat of French invasion as an imminent one.

13 "The increased advantages derived by the Bank from war conditions and war loans" had not escaped Chancellors of the Exchequer (Sir Henry Petty, Committee of Treasury Books 5, March 1806). Consequently, management fees charged to the Treasury were lowered by Perceval in early 1808 . Shortly before, the Bank had increased its yearly dividends to 10 percent (Clapham 1944).
} 


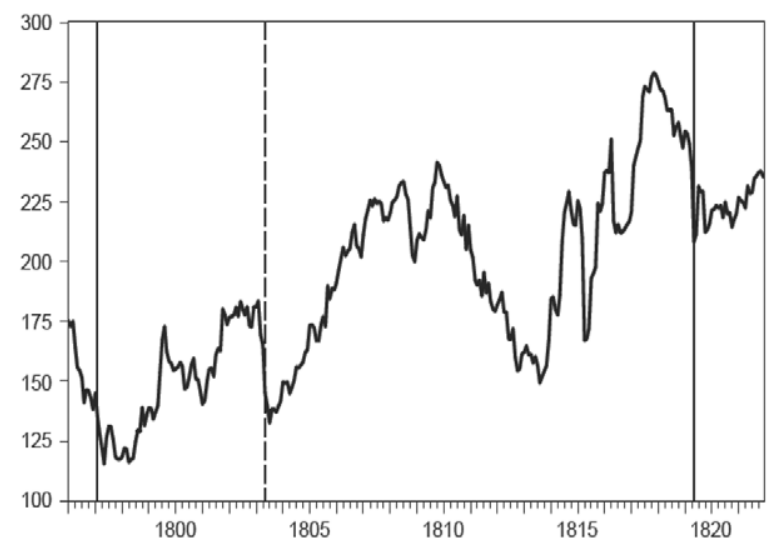

FIGURE 4

STOCK PRICE BANK OF ENGLAND, DEFLATED BY AGIO, JANUARY 1797=100, JANUARY 1796 TO DECEMBER 1821

Notes: The solid right and left lines mark the suspension and the decision to end the latter in February 1797 and May 1819, respectively. The dashed line depicts the beginning of renewed hostilities between Britain and France in May 1803.

Sources: Neal 1990.

that cause as well, since it implied that borrowing continued when warrelated expenses ceased. ${ }^{14}$

\section{THE LONG PATH TO RESUMPTION}

Having won the war against France, fiscal pressure delayed resumption of the gold standard. The Bank Restriction Act had initially determined that specie payments would be resumed six months after the end of the war. But between the end of the Napoleonic Wars in June 1815 and the resumption of the gold standard, the legal limit was extended several times, carrying the restriction to the 5th of July 1819 with resumption occurring slowly and only fully in $1821 .{ }^{15}$

\footnotetext{
${ }^{14}$ Winding down the Army and the Navy was costly; so were the public measures necessary to cope with post-war depression (Clapham 1944; Flinn 1961). On the contrary, the presence of Wellington's army as occupation forces in France between June 1815 and September 1818 was not detrimental to Britain's public finances. As stipulated by the Second Treaty of Parissigned after Napoleon's final defeat-France had to cover the related expenses. Moreover, Wellington's presence in France reassured British holders of newly issued French debt and guaranteed that war reparations were duly paid (Oosterlinck, Ureche-Rangau, and Vaslin 2014).

${ }^{15}$ The different pieces of legislation are summarized in the Report from the Secret Committee on the Expediency of the Bank Resuming Cash Payments of 1819.
} 
In the immediate post-war period, Bank directors insisted that an effective resumption was only possible if the government reimbursed a substantial portion of debt to due to the Bank. ${ }^{16}$ The argument was acknowledged in the parliamentary report preparing the resumption of the gold standard: "The effect [..] of the extent of the advances to Government upon the situation of the Bank, when preparing for a resumption of cash payments, is evidently to cramp its operations, by placing a large proportion of its issues beyond its control." ${ }^{\prime 17}$ Along with the definite resumption of specie payments, Peel's Act, enacted 2 July 1819, a separate act imposed the repayment of $£ 10$ million of government short-term debt and forbade the Bank to lend to government for more than three months without express parliamentary approval. ${ }^{18}$

These legislative actions determined the modalities of resumption. The suspension of cash payments was to be maintained until 31 January 1820. Following that date, the Bank would gradually resume payments, by exchanging its notes against ever higher amounts of specie between 1 February 1820 and 1 May $1823 .{ }^{19}$ Discretion was left to the Bank of England to accelerate resumption, granted that any increase in the pound's gold content had to be irreversible. At the same time, the Bank of England was to be repaid gradually the $£ 10$ million of government short-term debt.

Cash payments were finally resumed at the mint rate on 1 May 1821. It appears that the plan for gradual resumption and debt reimbursement was credible in the eyes of contemporaries. Upon the plan's announcement in May 1819, bank stocks and gold reacted immediately, suffering sizable declines in value; and the pound's exchange rate on Paris appreciated. The London Times lead article of 27 May asserted that resumption would ultimately succeed. Yet, neither cash payments nor effective debt reimbursement had begun: as late as January 1820, the Bank was still pressing the Treasury for repayment (Clapham 1944). The change in market sentiment and its impact on asset prices hinged on the mere anticipation of an important debt reduction that came with the reversion to the old monetary standard.

\footnotetext{
${ }^{16}$ The Bank's holdings of public securities had increased by 40 percent between February 1816 and August 1818.

${ }^{17}$ Report from the Secret Committee on the Expediency of the Bank Resuming Cash Payments of 1819 .

1859 Geo. III, c. 76.

${ }^{19}$ Since the publication of the Bullion Report in 1810, it had been broadly acknowledged that the resumption would have to be undertaken gradually over a period of at least two years (Cannan 1919). Earlier on - namely after the Peace of Amiens in 1802 - the six months after the ratification of a definitive peace treaty were thought sufficient for resuming the gold standard (Geo. III, c1).
} 
ECONOMETRIC METHODOLOGY

\section{The Data}

The agio, the difference between the pound's exchange rates on the spot and forward markets, captures how credible the promise of resuming the gold standard at its pre-war parity was in the eyes of contemporaries. The public, and the Bullion Committee in particular, used the agio to form an idea regarding the fluctuations in the pound's internal value and to assess inflationary tensions more broadly. Classical value theory held that the equilibrium price of a good was determined by its production costs (Ricardo 1817). As the production prices of gold and silver were relatively stable over the period, a rise in the sterling price of gold bullion, and hence, an increase in the difference between the mint price and the market price of gold, was perceived as evidence of inflation.

Evolution in the agio reflected the internal conditions of the British gold market well. The external supply of gold was stable during the Restriction Period because there were no major gold or silver discoveries (Barro 1987). Melting down and export of British coin were prohibited; the Continental Blockade and British counter measures made smuggling more costly. Finally, there is no reason to assume, that the demand for non-monetary uses of gold changed during the Restriction Period. Thus, price increases for precious metals in times of financial or political turmoil most likely reflected precautionary monetary motives, that is, a hedge against future inflation.

The data set spans the years 1750-1850 and is based on Castaing's and-later on-Wettenhall's Course of the Exchange, published twice a week. As noted earlier, the agio, shown in Figure 1, was essentially stable and close to zero over the period, ${ }^{20}$ except for the Restriction Period, where it rose above 10 percent after 1808 and reached a peak of 45 percent mid-1813. ${ }^{21}$ With no significant changes in the supply of gold, these evolutions meant a sizable internal devaluation of the pound: an increase of gold's market value in terms of paper pounds meant that more pounds were required to purchase the same amount of gold. ${ }^{22}$ Table 1 provides descriptive statistics for the agio with the agio being on average

${ }^{20} \mathrm{Li}$ (1963) analyzes the evolutions in the agio before the suspension period and points out that the market value of gold exceeded the mint price between 1757 and 1773, that is, before the recoinage of 1774 , by 1.75 percent on average due to the deterioration in coin quality.

${ }^{21}$ The absence of fluctuations in the agio between May 1802 and October 1808 is discussed in the section treating interest rates on public debt.

${ }^{22}$ In 1717 , Newton fixed the pound sterling at a gold price of $£ 317 \mathrm{~s} 10.5 \mathrm{~d}$. This mint price lasted, with lapses, for the two restriction periods until 1931. 
TABLE 1

DESCRIPTIVE STATISTICS FOR THE AGIO (MONTHLY DATA)

\begin{tabular}{lcccc}
\hline \hline & $\begin{array}{c}\text { Whole sample } \\
1750-1850\end{array}$ & $\begin{array}{c}\text { Pre-restriction } \\
1750-1797\end{array}$ & $\begin{array}{c}\text { Restriction Period } \\
1797-1821\end{array}$ & $\begin{array}{c}\text { Post-restriction } \\
1821-1850\end{array}$ \\
\hline Mean & 0.09 & 0.02 & 0.35 & -0.01 \\
Median & 0.00 & 0.00 & 0.11 & -0.01 \\
Maximum & 1.79 & 0.19 & 1.79 & 0.01 \\
Minimum & -0.04 & -0.04 & -0.02 & -0.02 \\
St. Deviation & 0.27 & 0.05 & 0.45 & 0.01 \\
Skewness & 3.95 & 1.44 & 1.54 & -082 \\
Kurtosis & 19.45 & 4.04 & 4.39 & 3.33 \\
Jarque-Bera & 16,818 & 219.72 & 137.89 & 40.97 \\
Probability & 0.00 & 0.00 & 0.00 & 0.00 \\
Observations & 1,212 & 566 & 291 & 355 \\
\hline
\end{tabular}

Sources: Author's calculations, data see text.

substantially higher and more volatile during the suspension than for the rest of the sample.

The agio contains information on inflationary tensions. For the available monthly and yearly price indices, correlation coefficients, shown in Table 2, ranged from 0.53 to 0.72 . It is noteworthy, that the correlation between the agio and the different price indices is higher for domestic goods and increases substantially for the Restriction Period, ranging from 0.65 to 0.79 . This is indicative of the fact that the agio reflected the internal value of the paper pound. An increase in the agio meant a decline in the purchasing power of the paper pound: aggregate prices and the agio varied in the same direction at a time when Britain's payment system rested on the paper pound.

\section{Identification Strategy: Contemporaries' Views and Actions}

Regardless of prior policy commitments, agents could rationally be expected to take into account all available information that could help anticipate the future state of public finances. If, for instance, the fiscal outlook looked grim, debt relief by devaluation would become more likely. The discrepancies between the publicly advertised parity at which resumption was to happen and contemporaries' beliefs were manifested in the agio, which reflected agents' assessment of fiscal sustainability in the future. Important changes in the agio conveyed information on the events that caused contemporaries to alter their predictions regarding public finances and a possible ensuing need for devaluation. 
TABLE 2

CORRELATION COEFFICIENTS BETWEEN THE AGIO AND PRICE INDICES

\begin{tabular}{lcc}
\hline \hline & $\begin{array}{c}\text { Whole sample } \\
(1750-1850)\end{array}$ & $\begin{array}{c}\text { Restriction Period } \\
(1797-1821)\end{array}$ \\
\hline $\begin{array}{l}\text { Monthly indices } \\
\text { Gayer, Rostow, and Schwartz (1953) }\end{array}$ & & \\
Total goods & 0.72 & 0.72 \\
Domestic goods & 0.72 & 0.69 \\
Imported goods & 0.64 & 0.65 \\
Yearly indices & & \\
Broadberry et al. (2012) & 0.59 & 0.79 \\
Clark (2014) & 0.53 & 0.74 \\
Schumpeter (1938) & 0.66 & 0.69 \\
\hline
\end{tabular}

Sources: Author's calculations, data see text.

These unexpected events should be identifiable as structural breaks in the agio. ${ }^{23} \mathrm{~A}$ battle lost by the British or a British victory, if that was either extremely costly or if it increased the likelihood that the war would last longer than expected, both implied adverse fiscal consequences.

Structural break analysis is different from an event study or the narrative approach, as the starting point is not a predefined list of historically important dates with the data telling which of them matter. Rather, the methodology detects those events that contemporaries considered to be significant for the future course of British finances without any ex post bias. This focuses attention on the concern that historical events are not merely a prequel to what ensues but have to be analyzed in their historical context.

\section{Archival Evidence: The Press and the Bank}

This approach does, however, bear the risk of "over-interpretation," that is, the risk that historical events of minor importance are matched with the determined break dates at any cost. I verify the importance of events matched with detected break dates by considering contemporary sources and archival evidence. In particular, I consult the London Times, for which archives are available over the whole period (Bignon and Flandreau 2014). I also examine the London Gazette, the government's official journal. This was published twice a week (on Tuesdays and Saturdays) and as a Gazette Extraordinary whenever deemed necessary

\footnotetext{
${ }^{23}$ Market efficiency entails that expected events would have been incorporated beforehand.
} 
by the nature of the news. The London Gazette contained official government announcements, such as declarations of war and peace, and intelligence from different war fronts. The news came in the form of dispatches, composed by the actors of war themselves (to a lesser extent that was the case for the London Times as well).

These sources also conveyed information regarding transmission times for news. For instance, Madrid capitulated to the French on 4 December 1808. News of the capitulation, however, only reached London on 19 December. I, consequently, pay close attention to the fact that break dates have to coincide with the moment at which information concerning an event reached London, rather than with the timing of the event itself.

While it is rather straightforward that Madrid's capitulation made the news in December 1808, it is less easy to determine which event affected contemporaries' perceptions, when there were several important battle lines. In these cases, I search the Times and the Gazette for keywords in the vicinity of the break date and retain the event yielding the highest number of references. I pay particular attention to the frequency of mentions in the London Times lead articles. In August 1812, for example, intelligence from neither the Russian nor the Spanish fronts made the headlines; rather the American declaration of war occupied most news space.

In addition to these sources, I rely on ledgers and related documents from the Bank of England Archives that contain prices for precious metals, exchange rates, and different titles of public debt. ${ }^{24}$ The ledgers recorded events significant to the Bank, establishing a link between observed price movements and the incidents that caused them. In other words, contemporaries were well aware of the fact that political and military events had a bearing on the evolution of asset prices. The ledger (10A2702) recorded fortnightly averages of the aforementioned price data and was compiled in real time for the years 1705 to 1880 . This makes the ledger a reflection of how events were understood as they unfolded. It is, therefore, reassuring that practically all estimated break dates and related events, discussed in the next section, are mentioned in the ledger.

My approach is inspired by Steven B. Webb (1986) in that it allows detection of events that influenced contemporaries' perceptions in real time, by combining ex-ante agnostic break tests with the study of contemporary sources. The Online Appendix provides an example of how this

\footnotetext{
${ }^{24}$ Bank of England Archives, items 10A270/1 and 10A321/1.
} 
methodology forestalls detecting events that suffer from ex post bias. For example, historiography regards the Battle of Leipzig in October 1813 as Napoleon's decisive defeat, yet contemporaries' perception of the event explains why it did not affect asset prices; the British victory was anticipated and was not expected to alleviate fiscal strain.

Various studies in economic history (Guinnane, Rosen, and Willard 1996; Brown and Burdekin 2000; Flandreau and Oosterlinck 2012) have relied on break point tests. The procedure used here to estimate break dates is based on Jushan Bai and Pierre Perron (1998, 2003). It has the advantage of allowing for a very wide range of specifications (serial correlation and heteroskedasticity in the errors, lagged dependent variables, trending regressors, as well as different distributions for the errors and the regressors across different segments). The procedure also encompasses different break point tests (sequential and global methods), increasing the robustness of the results.

Consider the following multiple linear regression model with $m$ breaks and $m+1$ regimes:

$$
y_{t}=x_{t}^{\prime} \beta+z_{t}^{\prime} \delta_{j}+u_{t},
$$

for $t=T_{j-1}+1, \ldots, T_{j}$ and $j=1, . ., m+1 . y_{t}$ is the observed endogenous variable, $x_{t}(p \times 1)$ and $z_{t}(q \times 1)$ are vectors of co-variates and $\beta$ and $\delta_{j}$ are the corresponding vectors of coefficients. $u_{t}$ is the disturbance at time $t$. Given the $T$ observations of $\left(y_{t} x_{t} z_{t}\right)$, I estimate the unknown regression coefficients $\beta$ and $\delta_{j}$ and break dates. For the agio, I will posit that all coefficients are subject to change, obtaining a pure structural change model $(p=0)$ of the following form:

$$
y_{t}=z_{t}^{\prime} \delta_{j}+u
$$

Note that the variance of $u_{t}$ does not need to be constant. Breaks in the variance are permitted, provided they occur at the same dates as the breaks in the parameters of the regression.

I define a break in the series as a change in the conditional mean of the series $y_{t}$, that is, I specify that the intercept can change $\left(z_{t}=1\right)$. The focus here is on abrupt structural changes in the mean that reflect the advent of unexpected news affecting Britain's war fate and, hence, public finances. For that reason, I exclude past values of the endogenous $y_{t}$. When lagged variables are included, changes in the level of $y_{t}$ also depend on the autoregressive dynamics of the series; thus, the change takes effect gradually. 
Conversely, when specifying $x_{t}=\varnothing$, all the dynamics are contained in the error term and the change is abrupt (Bai and Perron 2003). ${ }^{25}$

I first run the break point procedure on monthly data for the 1795-1823 period. This data set is comparable to the ones used in earlier studies (Neal 1990) and contains 340 observations. I then use biweekly data, in order to more precisely detect break dates. Due to data availability issues, I estimate biweekly break dates only for July 1810 to May 1823 . The biweekly data set encompasses 1,350 observations.

Increasing the number of observations included in the sample allows detecting more break dates, as the number of breaks depends on the size of segments (the number of observations between two adjacent breaks). A minimal segment size guarantees that each segment contains sufficient observations to estimate parameters precisely. Furthermore, I ignore break dates indicated as imprecisely estimated by a large confidence interval. ${ }^{26}$

In the presence of autocorrelation and heteroskedasticity, as is the case here, each segment should include at least 24 observations. A trimming parameter, $\varepsilon$, links the minimal segment size, $h$, to the maximal number of breaks, $k$, allowed: $\varepsilon=h / T$. For a sample of $T$ observations one obtains the maximal number of breaks, $k: \varepsilon=0.05 \rightarrow k=10 ; \varepsilon=0.10 \rightarrow k=8 ; \varepsilon$ $=0.15 \rightarrow k=5 ; \varepsilon=0.20 \rightarrow k=3 ; \varepsilon=0.25 \rightarrow k=2$.

\section{RESULTS}

\section{Monthly Results for the Agio}

The monthly break dates for the agio are displayed in Figure 5 and Table 3. The size of the agio's shifts is measured by the percentage change between the agio at the detected break date and the agio's reference value, scaled to 100 in January $1797 .{ }^{27}$ This measure can be understood as the cumulative de-or appreciation of the pound in terms of gold

${ }^{25}$ When no lagged variable is part of $\left(x_{t}, z_{t}\right)$, the conditions on the residuals allow for autocorrelation and heteroskedasticity.

${ }^{26}$ For the biweekly series, one such date in July 1813 was excluded from the list of breaks.

${ }^{27}$ Measuring the size of the agio's shifts this way carries the implicit and strong assumption that the agio would return to the same level after the resumption of the gold standard, but allows for a fixed reference point, rendering the size of shifts comparable over time. An alternative measure for the size of the agio's shifts would be to quantify the changes in the agio's level between break dates and the observation preceding them. Given changes in the anticipated mint ratio, the so-calculated changes would, however, not be comparable over time. 


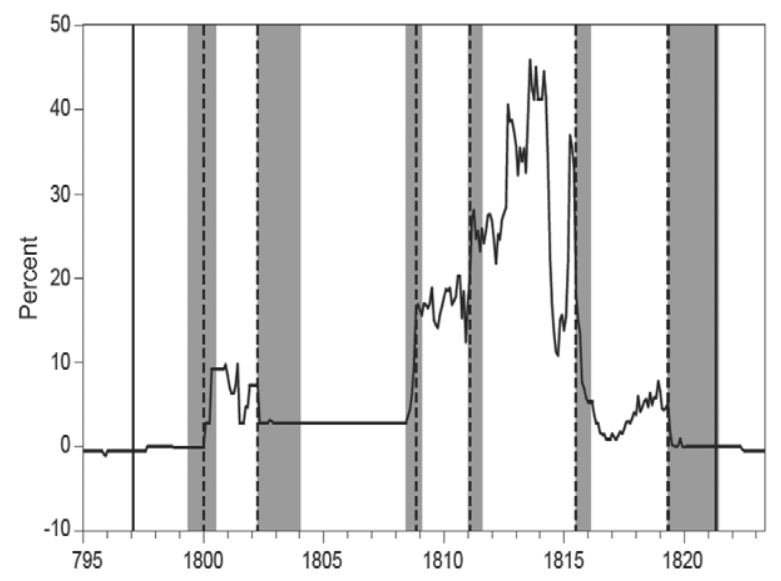

FIGURE 5

BREAK DATES IN THE AGIO, MONTHLY DATA, JANUARY 1795 TO MAY 1823

Notes: Solid lines mark the beginning and end of the gold standard's suspension, February 1797 and May 1821, respectively. Dashed lines highlight the detected break dates; the shaded areas represent the 95 percent asymmetric confidence intervals.

Sources: Author's calculations.

at any given break date. The events that coincided with the detected break dates are outlined:

January 1800: The winter of 1799 brought Napoleon to power as first Consul of France, a position granting him broad and unchecked authority. Given his military successes during the war of the First Coalition (17921797), his accession to power was thought to reestablish France's place in the concert of nations (Mignet 1826). When Britain declined Napoleon's offers to begin peace negotiations, announced in the London Times on 6 January 1800 , the agio increased to 3 percent, which corresponded to a 3 percent depreciation of the pound in terms of gold. Market sentiment proved right in that the following months would prove unfavorable for Britain. The battles of Marengo (14 June 1800) and Hohenlinden (3 December 1800) sealed Austria's defeat, leaving the British as the only army opposing France.

April 1802: The Treaty of Amiens ended hostilities between the French Republic and the United Kingdom and, thus, the war of the Second Coalition (1798-1802). At the same time, the Bank of England had signaled its readiness to resume convertibility on several occasions (Clapham 1944; Chadha and Newby 2013). ${ }^{28}$ These events were favorable

\footnotetext{
${ }^{28}$ It was the government that had urged parliament, on two occasions, to extend the act, until a new war would end discussions about resumption.
} 
TABLE 3

BREAK DATES FOR THE AGIO, MONTHLY DATA-JANUARY 1795 TO MAY 1823

\begin{tabular}{|c|c|c|c|c|c|c|}
\hline Break Date & \multicolumn{5}{|l|}{ Event } & Agio \\
\hline January 1800 & \multicolumn{5}{|c|}{ Coup of 18 Brumaire and ensuing constitution install Napoleon as sole ruler over France } & $\pi$ \\
\hline April 1802 & \multicolumn{5}{|c|}{ Treaty of Amiens ends hostilities between France and Britain } & $y$ \\
\hline November 1808 & \multicolumn{5}{|c|}{ Napoleon's brother Joseph becomes King of Spain after French victories at Tudela and Somosierra } & $\pi$ \\
\hline February 1811 & \multicolumn{5}{|c|}{ French forces nearly destroy Spanish Army of Extremadura and capture Badajoz } & $\pi$ \\
\hline July 1815 & \multicolumn{5}{|c|}{ Prussians seize Paris, Napoleon surrenders to the British } & ע \\
\hline May 1819 & \multicolumn{5}{|c|}{ Peel's Act definitely fixes details and timing for resumption of convertibility } & $y$ \\
\hline Break date & $01 / 1800$ & $04 / 1802$ & $11 / 1808$ & $02 / 1811$ & $07 / 1815$ & 05/1819 \\
\hline Confidence interval & $5 / 1799-7 / 1800$ & $04 / 1802-01 / 1804$ & $06 / 1808-02 / 1809$ & 01/1811-08/1811 & $07 / 1815-02 / 1816$ & $05 / 1819-06 / 1821$ \\
\hline Regime & 01/1795-01/1800 & $02 / 1800-04 / 1802$ & $12 / 1802-11 / 1808$ & $12 / 1808-02 / 1811$ & $10 / 1811-07 / 1815$ & $08 / 1815-05 / 1819$ \\
\hline Constant & -0.01 & 0.23 & 0.12 & 0.73 & 1.17 & 0.17 \\
\hline Observations & 61 & 27 & 72 & 27 & 46 & 46 \\
\hline
\end{tabular}

Sources: Author's calculations, data see text. 
to Britain, and upon their announcement on 29 and 30 March in the London Gazette and the London Times respectively, the agio decreased to 3 percent. ${ }^{29}$

November 1808: The battle of Burgos (10 November, announced in the London Times on the $26^{\text {th }}$ ) resulted in the complete victory of the French over the Spanish, and opened central Spain to invasion. The battle preceded Madrid's capitulation on 4 December and the installation of Napoleon's brother Joseph as the King of Spain. In line with these events, the agio increased to 16 percent.

February 1811: An outnumbered French force nearly destroyed the Spanish Army of Extremadura at the battle of Gebora (19 February). This victory allowed the French to seize the important fortress and wellsupplied town of Badajoz, opening the route to Portugal. The siege of Badajoz and the city's strategic importance are first mentioned in the London Times by mid-February. The city's fall is announced in the London Times on the 12th of March, which is included in the confidence interval. On this occasion, the agio increased further to 28 percent.

July 1815: The month of July witnessed decisive military events, sealing Napoleon's final defeat. Wellington and Louis XVIII entered Paris after the Battle of Issy, won on the $3^{\text {rd }}$ of July..$^{30}$ On 15 July, Napoleon surrendered to the British ${ }^{31}$ and was sent to the island of Saint Helena, where he died in May 1821. In line with these events, the agio decreased to 18 percent.

May 1819: Peel's Act definitively fixed the details and timeline for the resumption of the gold standard (see next section). On this occasion, the agio decreased to 2 percent. ${ }^{32}$

\section{Biweekly Results for the Agio}

Break date estimation on biweekly data for the agio are presented in Figure 6 and Table 4 . The results for overlapping periods from the daily procedure corroborate the monthly results and provide greater definition of events leading to changes in the agio.

\footnotetext{
${ }^{29}$ The large confidence interval surrounding this break date is due to the absence of variation in the agio between May 1802 and October 1808 (see section treating interest rates on public debt).

${ }^{30}$ London Gazette, 11 July.

${ }^{31}$ London Gazette, 21 July.

${ }^{32}$ The large confidence interval surrounding this break date is due to the absence of variation in the agio afterward. Once resumption was definitively decided in May 1819, the agio returned to the level and volatility observed before the suspension of the gold standard.
} 


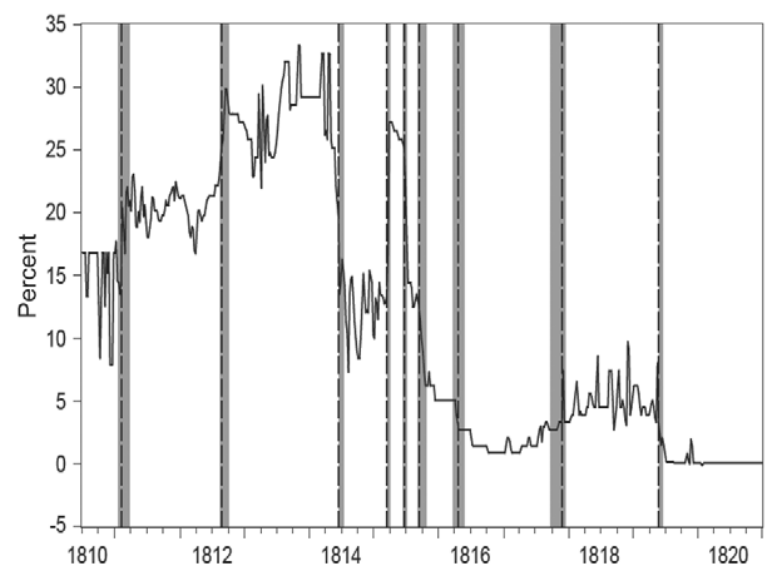

FIGURE 6

BREAK DATES IN THE $A G I O$, BIWEEKLY DATA, JULY 1810 TO DECEMBER 1820

Notes: Dashed lines highlight the detected break dates; the shaded areas represent the 95 percent asymmetric confidence intervals.

Sources: Author's calculations.

8 February 1811: No military or political events occurred at this exact date. However, the confidence interval encompasses the battle of Gebora and the ensuing fall of Badajoz (February 1811). Following these events, the agio on gold increased to 28 percent.

25 August 1812: During the summer of 1812, a great deal of uncertainty surrounded the war with America, causing upheaval in the trading community and fluctuations in the funds. ${ }^{33}$ While the American declaration of war had reached London by the end of July, its primary cause, Britain's demand that the United States cease trade with France, had already been revoked. It was, thus, expected that Lord Liverpool's repeal of the Orders of Council would put an end to hostilities. It came as a surprise when news regarding the American decision to continue warfare reached London towards the end of August. ${ }^{34}$ The opening up of a new war front amid ongoing war in the Peninsula caused a rise in the agio to 35 percent.

17 June 1814: The Treaty of Paris, signed on 30 May 1814, ended the War of the Sixth Coalition. The peace treaty and its ratification were published in the London Gazette on the $2^{\text {nd }}$ and $18^{\text {th }}$ of June. As restoring a strong and stable French state was part of returning to the pre-Napoleonic

${ }^{33}$ London Times, 21 August and 4 September.

${ }^{34}$ London Times, 21 August and 4 September. 
TABLE 4

BREAK DATES FOR THE AGIO, DAILY DATA-JULY 1810 TO MAY 1823

\begin{tabular}{|c|c|c|c|c|c|}
\hline Break Date & \multicolumn{4}{|c|}{ Event } & Agio \\
\hline 8 February 1811 & \multicolumn{4}{|c|}{ French victory at Gebora, capture of Badajoz } & $\pi$ \\
\hline 25 August 1812 & \multicolumn{4}{|c|}{ American declaration of war } & $\pi$ \\
\hline 17 June 1814 & \multicolumn{4}{|c|}{ Treaty of Paris temporarily ends Napoleonic Wars } & $y$ \\
\hline 17 March 1815 & \multicolumn{4}{|c|}{ Napoleon enters Paris after having escaped his exile on Elba } & $\pi$ \\
\hline 23 June 1815 & \multicolumn{4}{|c|}{ Napoleon suffers his decisive defeat at Waterloo } & $y$ \\
\hline 15 September 1815 & \multicolumn{4}{|c|}{ Ultimatum regarding second Treaty of Paris } & $y$ \\
\hline 16 April 1816 & \multicolumn{4}{|c|}{ Currency reform } & $y$ \\
\hline 28 November 1817 & \multicolumn{4}{|c|}{ Post-war depression, public debt issues, and political upheaval } & $\pi$ \\
\hline 28 May 1819 & \multicolumn{4}{|c|}{ Peel's Act ushers in resumption; reimbursement of public debt } & $y$ \\
\hline Break date & $08 / 02 / 1811$ & $25 / 08 / 1812$ & $20 / 07 / 1813$ & $17 / 06 / 1814$ & $17 / 03 / 1815$ \\
\hline Confidence interval & $22 / 1 / 1811-22 / 3 / 1811$ & 21/08/1812-02/10/1812 & $13 / 04 / 1813-17 / 08 / 1813$ & $14 / 06 / 1814-15 / 07 / 1814$ & $14 / 03 / 1815-31 / 03 / 1815$ \\
\hline Constant & 0.68 & 1.00 & 1.40 & 1.59 & 0.56 \\
\hline Observations & 63 & 161 & 94 & 95 & 78 \\
\hline Break date & $23 / 06 / 1815$ & $15 / 09 / 1815$ & $16 / 04 / 1816$ & $28 / 11 / 1817$ & $28 / 05 / 1819$ \\
\hline Confidence interval & $13 / 06 / 1815-04 / 07 / 1815$ & 05/09/1815-20/10/1815 & 19/03/1816-21/05/1816 & 26/09/1817-09/12/1817 & $25 / 05 / 1819-18 / 06 / 1819$ \\
\hline Regime & $21 / 03 / 1815-23 / 06 / 1815$ & $27 / 06 / 1815-15 / 09 / 1815$ & $19 / 09 / 1815-16 / 04 / 1816$ & 19/04/1816-28/11/1817 & $02 / 12 / 1817-28 / 05 / 1819$ \\
\hline Constant & 1.35 & 0.69 & 0.24 & 0.07 & 0.20 \\
\hline Observations & 28 & 52 & 61 & 169 & 156 \\
\hline
\end{tabular}

Sources: Author's calculations, data see text. 
balance of power, Britain relinquished reparation payments. The counterpart to this was eliminating the French threat to Britain's commercial interests around the world (White 2001). On this occasion, the agio fell to 16 percent.

17 March 1815: After escaping his exile on Elba, Napoleon entered Paris on 20 March. $^{35}$ Upon reaccession to the throne, he started to organize his armed forces. By the end of May, he had formed "l'Armée du Nord," consisting of approximately 200,000 troops ready for deployment in the Waterloo Campaign (Chesney 1868). At the mere prospect of a new war against Napoleon, the agio rose to 38 percent. The evolution of the agio in response to this particular event emphasizes that it is the expectation of future public spending that affects the internal value of the pound. This is clearly a fiscal news shock, as no war-related spending had yet occurred, which rules out the hypothesis that inflationary tensions were caused by monetary expansion.

23 June 1815: Napoleon suffered his decisive defeat at Waterloo on 18 June, ending his Hundred Days of reign. ${ }^{36}$ At this point, the agio declined to 24 percent.

15 September 1815: Negotiations for the second Treaty of Paris were set in motion when the Allies delivered an ultimatum to the French government for a new peace treaty on 20 September. ${ }^{37}$ This time, the Allies' demands included sizable reparation payments, to be disbursed over the following five years. Absent any bargaining power for the newly restored Bourbon monarchy (White 2001), the agio decreased in line with this event to 14 percent.

16 April 1816: Although the Restriction Period was due to end on 5 July 1816 , the government postponed resumption for another two years in midApril. The public still remained sanguine regarding resumption, since the government's prior currency reform was understood as a necessary step towards stabilization of the pound (Clapham 1944). The gold standard was officially adopted, and bimetallism was abandoned by the Coinage Act of 1816, also known as Liverpool's Act. ${ }^{38}$ The act installed gold as the sole standard of value, complementing gold coinage by a token silver coinage; the legal tender of silver coins was limited to $£ 2$ (Redish 1990; Sargent and Velde 2002). The agio on gold declined to 5 percent.

\footnotetext{
${ }^{35}$ London Times, 24 March.

${ }^{36}$ London Gazette, 22 and 24 March.

${ }^{37}$ London Times, 7 and 10 October.

${ }^{38} 56$ Geo. III, c. 68 .
} 
28 November 1817: Post-war depression and deflation started in Britain in early 1816 (Broadberry et al. 2012; Clapham 1944). Due to a bad harvest and the Corn Laws, wheat and bread prices rose. Eventually, this combination caused social unrest. The political status quo was called into question by riots calling for electoral reform and universal suffrage (see also Dasgupta and Ziblatt 2015). A prerequisite for becoming a member of parliament were property qualifications that guaranteed an important intersection between members of parliament and creditors of public debt (Johnston 2013). Since deflation increased the real value of debt to the advantage of creditors, parliamentary support for reimbursement of public debt was strong. Universal suffrage could have seriously challenged this. ${ }^{39}$ In this situation, a new issue of Exchequer Bills (Flinn 1961) and the abolition of the income tax further increased government's outstanding short-term debt, making resumption of cash payments less probable (Clapham 1944). The agio rose again to 9 percent.

28 May 1819: Parliamentary debates regarding the resumption of convertibility started on 21 May and concluded unanimously on 26 May, stating the exact resolutions governing the resumption of specie payments. ${ }^{40}$ The final version of Peel's Act (59 Geo. III c49) was made law by 2 July 1819 and provided for gradual resumption of payments at the pre-war parity over a period of four years. Indeed, John Clapham (1944) emphasizes the immediate impact the new regulation had on the Paris exchange. The agio on gold fell to 2 percent.

Overall, the detected break dates coincide with events that prompt a revision of expectations regarding public finances. The events come from a close reading of contemporary newspapers and are corroborated by an analysis of ledgers in the archives of the Bank of England, which clearly link military and political events to the evolution of asset prices. It is reassuring that practically all estimated break dates are also mentioned in the ledger (see section on archival evidence).

\section{Interest Rates on Public Debt}

The agio did not fluctuate between May 1802 and October 1808 (see Figure 1). Data are available until October 1805. For the period spanning

\footnotetext{
${ }^{39}$ The most ardent proponents of maintaining the paper pound indefinitely could be found among industrialists in the north of Britain (Clapham 1944). Not only did the northern parts of the kingdom suffer economically, they were also lacking political representation. Manchester and Birmingham, for instance, had a population of 100,000 each, but were not represented by members of parliament at the national level.

${ }^{40}$ Hansard HC Deb, 26 May 1819, vol. 40, cc802-04.
} 
the years from 1805 to 1808 the agio's stability simply reflects the lack of observations. I, therefore, study another series that captured contemporaries' expectations of how debt would be stabilized. In particular, (warrelated) news that came with fiscal consequences should have affected the interest rate at which the Treasury borrowed in the same way it influenced the agio.

Figure 7 displays the evolution of the market yield on 3 percent consolidated annuities, the Consol, between January 1805 and December 1808. The latter formed the largest part of Britain's funded debt before WWI and were the benchmark instrument of British debt management over the period. ${ }^{41}$ Consols were a perpetual bond, for which holders received a 3 percent coupon. The yield of a consol equaled interest payments as a percentage of the market price. In the absence of default risk, yields, thus, reflected price movements on the secondary market that primarily incorporated investors' expectations of inflation (Chamley 2011). Table 5 shows the break dates estimated on a sample of 1250 daily observations, and provides confidence intervals and parameter estimates. The detected break dates coincided with the following events:

14 November 1805: News regarding the British victory at Trafalgar (21 October) reached London on the $6^{\text {th }}$ of November. ${ }^{42}$ As the French and Spanish fleets were almost completely destroyed, the victory averted the danger of French invasion and established Britain's naval supremacy. Against this background, it was expected that Prussia would assist the coalition against Napoleon, at the very least, by acting as a mediator between the belligerents. ${ }^{43}$ In line with these events, the yield on consols declined to 5 percent.

14 June 1806: No military or political events occurred at this exact date. The London Times, however, mentioned that the price of consols rose substantially, entailing a decline in yields to 4.8 percent, since peace negotiations with France were expected to begin. ${ }^{44}$

8 October 1806: Peace negotiations with France were broken off. ${ }^{45}$ On this occasion, the yield increased to 4.9 percent. The stream of unfavorable news continued afterwards, when intelligence regarding the French victory over Prussia at Jena-Auerstedt (14 October) reached London. ${ }^{46}$

\footnotetext{
${ }^{41}$ As such they were not subject to redemption or interest rate reductions: from 1752 up until to Goschen's conversion in 1888, the coupon rate on consols remained at 3 percent.

${ }^{42}$ London Gazette, 6 November; London Times, 7 November.

${ }^{43}$ London Times, 15 and 19 November.

${ }^{44}$ London Times, 17 June.

${ }^{45}$ London Times, 9 October.

${ }^{46}$ London Times, 27 October.
} 


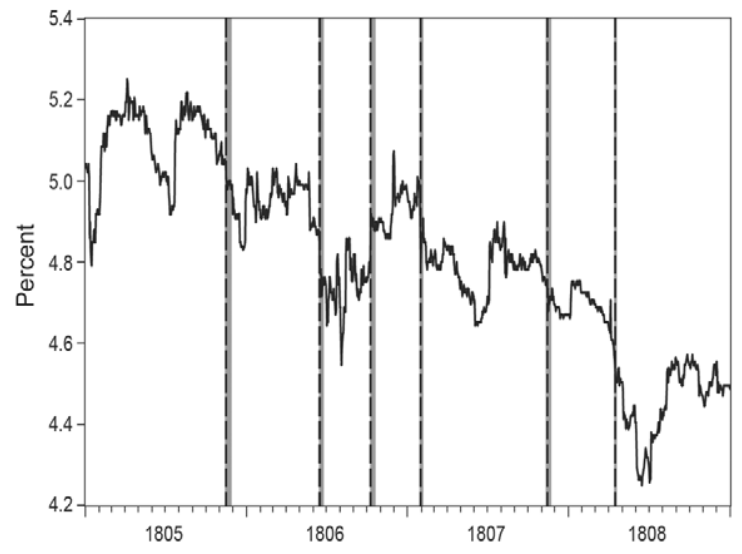

FIGURE 7

BREAK DATES FOR THE YIELD ON CONSOLS, DAILY DATA, JANUARY 1805 TO DECEMBER 1808

Notes: Dashed lines highlight the detected break dates; the shaded areas represent the 95 percent asymmetric confidence intervals.

Sources: Author's calculations.

29 January 1807: According to the 1807 budget, "the expenditure for this necessary war may be maintained to any indefinite period on the present scale, without any new taxes whatever." ${ }^{\prime 77}$ The London Times also pointed out that the new plan of finance was to "the manifest benefit to the interests of the public creditor." ${ }^{\prime 4}$ On this occasion, the yield on consols declined to 4.8 percent.

12 November 1807: Britain issued Orders in Council on 11 November, forbidding French trade with the United Kingdom, its allies, or neutrals and blocking French and allied ports. ${ }^{49}$ The measure was a response to the Berlin Decree (21 November 1806) that had initiated the Continental Blockade and Napoleon's attempt to harm British trade. While the British measure entailed a significant and lasting decline in yields, the French action did not substantially affect them. In the aftermath of the battle of Trafalgar, the Berlin Decree was not expected to be an impediment to British trade because of the French Navy's weakness. ${ }^{50}$ On this occasion, the yield on consols declined to 4.7 percent.

14 April 1808: The Chancellor of the Exchequer announced that there would be a primary surplus for the year. ${ }^{51}$ The expenses for running loans

\footnotetext{
${ }^{47}$ Hansard HC Deb, 29 January 1807, vol. 8, cc564-93; London Times, 30 January 1807.

${ }^{48}$ London Times, 2 February 1807.

${ }^{49}$ London Times, 10 November; London Gazette, 14 December.

${ }^{50}$ London Times, 8 December 1806.

${ }^{51}$ Hansard HC Deb 11 April 1808 vol. 11, cc11-8; London Times 12 and 13 April 1808.
} 
TABLE 5

BREAK DATES FOR THE YIELD ON CONSOLS, DAILY DATA-JANUARY 1805 TO DECEMBER 1808

\begin{tabular}{|c|c|c|c|}
\hline Break Date & \multicolumn{2}{|c|}{ Event } & Yield \\
\hline 14 November 1805 & \multicolumn{2}{|c|}{ Prussia expected to join coalition against Napoleon } & $y$ \\
\hline 14 June 1806 & \multicolumn{2}{|c|}{ Peace negotiations with France to begin } & $y$ \\
\hline 8 October 1806 & \multicolumn{2}{|c|}{ Peace negotiations with France broken off } & $\pi$ \\
\hline 29 January 1807 & \multicolumn{2}{|c|}{ War can be financed without new taxes } & $y$ \\
\hline 12 November 1807 & \multicolumn{2}{|c|}{ Orders in Council forbidding trade with France } & ע \\
\hline 14 April 1808 & \multicolumn{2}{|l|}{ Announcement of primary surplus } & ע \\
\hline Break date & $14 / 11 / 1805$ & $14 / 06 / 1806$ & 08/10/1806 \\
\hline Confidence interval & $13 / 11 / 1805-26 / 11 / 1805$ & $13 / 06 / 1805-25 / 06 / 1805$ & $07 / 10 / 1806-17 / 10 / 1806$ \\
\hline Regime & $01 / 01 / 1805-14 / 11 / 1805$ & $15 / 11 / 1805-14 / 06 / 1805$ & $16 / 06 / 1806-08 / 10 / 1806$ \\
\hline Constant & 5.10 & 4.95 & 4.74 \\
\hline Observations & 273 & 182 & 99 \\
\hline Break date & $29 / 01 / 1807$ & 12/11/1807 & $14 / 04 / 1808$ \\
\hline Confidence interval & $28 / 01 / 1807-7 / 02 / 1807$ & $11 / 11 / 1807-17 / 11 / 1807$ & $13 / 04 / 1808-16 / 04 / 1808$ \\
\hline Regime & 09/10/1806-29/01/1807 & $30 / 01 / 1807-12 / 11 / 1807$ & $13 / 11 / 1807-14 / 04 / 1808$ \\
\hline Constant & 4.93 & 4.78 & 4.69 \\
\hline Observations & 97 & 246 & 132 \\
\hline
\end{tabular}

Sources: Author's calculations, data see text. 


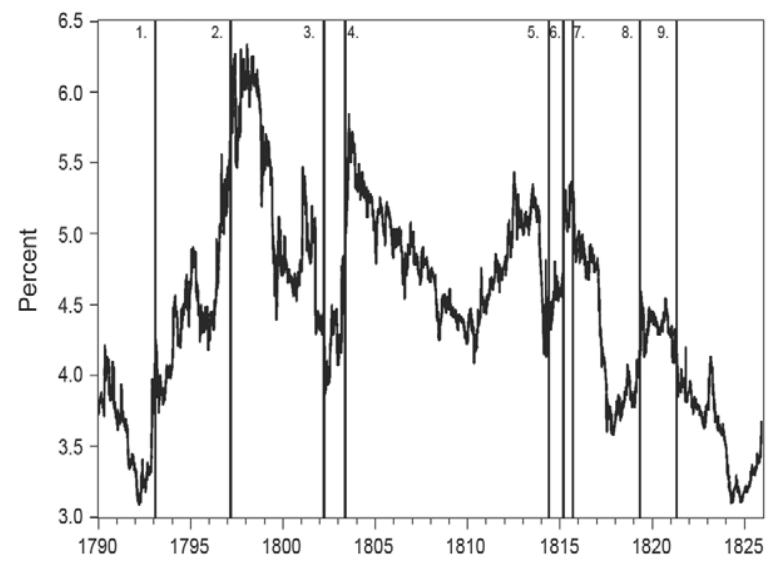

FigURE 8

THE YIELD ON CONSOLS, DAILY DATA, JANUARY 1795 TO DECEMBER 1825

Notes: Vertical bars mark the following events:

1. France declared war on Britain (1 February 1793)

2. Suspension of the gold standard (27 February 1797)

3. The Treaty of Amiens ended the war of the Second Coalition (25 March1802)

4. Britain declared war on France (17 May 1803)

5. The first Treaty of Paris ended the war of the Sixth Coalition (30 May 1814)

6. Napoleon returned from exile and organized his armed forces (20 March 1815)

7. Negotiations for second Treaty of Paris (20 September 1815)

8. Decision to resume the gold standard (26 May 1819)

9. Actual resumption of the gold standard (1 May 1821)

Sources: Neal 1990.

would be charged on the revenues of stamp duties. On this occasion, the yield on consols declined further to 4.5 percent.

Overall, the break dates for the interest rate on consols coincide with events that prompt a revision of expectations regarding public finances. The same is true for the break dates for agio, estimated for the periods for which data are available. Figure 8 presents the evolution of the yield on consols between 1795 and 1825 . The vertical bars mark certain political or military events that coincided with turning points in the yield series. For overlapping periods, the same events concurred with turning points in the agio. $^{52}$

${ }^{52}$ The decision to resume the gold standard in May 1819 is an interesting exception. On the occasion, the agio declined instantaneously to its pre-suspension level while the yield on consols increased. In order to pay off Exchequer bills - as imposed by 59 Geo. III, c. 76 - large loans were issued (Hansard HC Deb 2 June $1819 \mathrm{vol}$. 40, cc840-5). This was part of a broader funding scheme, converting Exchequer bills into longer-dated securities (58 Geo III c.25). These operations substantially increased the supply of funded debt, yields, therefore, rose. 
A more formal analysis of the returns on British consols was conducted by William Brown, Richard C. Burdekin, and Marc D. Weidenmier (2005) and revealed that the same types of event affected bond yields and the agio. For overlapping periods (1810-1823), shifts identified in the bond yield series were either identical to the break dates detected here (Napoleon returned from Elba in March 1815) or related to connected events (bond yields decreased by the end of March 1814 when Paris surrendered; the agio decreased in June 1814 when the Treaty of Paris ended the Napoleonic Wars).

\section{CONCLUDING REMARKS}

I studied the evolutions of the agio, a series that captured differences between the gold content of a paper pound in time $t$ and its expected value in the future. The discrepancies between these two exchange rates reflected how credible the promise of resuming the gold standard at its pre-war parity was in the eyes of contemporaries. My analysis showed that significant changes in the agio coincided with events that prompted a reassessment of Britain's expected military fate. In particular, on unfavorable news the pound's internal value declined, as these made British victory seem less probable and devaluation more likely. Conversely, favorable news caused the pound's purchasing power to increase.

The nature and timing of certain jumps in the agio allowed ruling out the hypothesis that inflationary tensions were caused by monetary expansion. When Napoleon reascended the throne in March 1815 after having escaped his exile on Elba the agio doubled. However, no war-related spending had yet occurred, rather it was the expectation of future public spending, a fiscal news shock, that affected the internal value of the pound.

Switching from the gold standard to a fiat currency regime, effectively replaced the risk of sovereign default with a risk from inflation (Calomiris and Haber 2014). As adjustments in the real value of outstanding debt could now be engineered through devaluations of the currency, monetary regime choices, and their operation shaped how people expected debt to be stabilized.

In terms of the long-standing debate attributing evolutions in the price level during the Restriction Period to either real or monetary factors, I put forward a third explanation: fiscal prospects affected the pound's internal value, that is, its exchange rate into gold. As Britain's payment system during the suspension period rested on the pound, this also had a bearing on evolutions in the aggregate price level more generally. 
Britain had well-functioning financial markets, which allowed for an increasing national debt. For a quarter of a century, Britain operated a fiduciary currency regime with flexible exchange rates, a feature that characterizes most industrialized economies today.

\section{REFERENCES}

Acworth, Angus W. Financial Reconstruction in England 1815-1822. London: P.S. King and Son LTD, 1925.

Bai, Jushan, and Pierre Perron. "Estimating and Testing Linear Models with Multiple Structural Changes." Econometrica 66, no. 1 (1998): 47-78.

_. "Computation and Analysis of Multiple Structural Change Models." Journal of Applied Econometrics 18, no. 1 (2003): 1-22.

Barro, Robert J. "Money and the Price Level under the Gold Standard." The Economic Journal 89 (1979): 13-33.

—. "Government Spending, Interest Rates, Prices, and Budget Deficits in the United Kingdom, 1701-1918.” Journal of Monetary Economics 20, no. 2 (1987): 221-47.

Bignon, Vincent, and Marc Flandreau. "The Price of Media Capture and the Debasement of the French Newspaper Industry During the Interwar." Journal of Economic History 74, no. 3 (2014): 799-830.

Bordo, Michael D., and Anna J. Schwartz. "Money and Prices in the 19th Century: Was Thomas Tooke Right?” Explorations in Economic History 18, no. 2 (1981): 97-127.

Bordo, Michael D., and Eugene N. White. "A Tale of Two Currencies: British and French Finance During the Napoleonic Wars." Journal of Economic History 51, no. 2 (1991): 303-16.

Boyer-Xambeu, Marie-Thérèse, Lucien Gillard, and Ghislain Deleplace. "Régimes monétaires, points d'or et serpent bimétallique de 1770 à 1870." Revue Economique 45, no. 5 (1994): 1139-74.

Brewer, John. The Sinews of Power. London: Century Hutchinson, 1988.

Broadberry, Stephen, Bruce Campbell, Alexander Klein, et al. "British Economic Growth, 1270-1870: An Output-based Approach.” Mimeo, 2012.

Brown, William O., and Richard C. K. Burdekin. "Turning Points in the U.S. Civil War: A British Perspective.” Journal of Economic History 60, no. 1 (2000): 216-31.

Brown, William O., Richard C. Burdekin, and Marc D. Weidenmier. "Volatility in an Era of Reduced Uncertainty: Lessons from Pax Britannica." Journal of Financial Economics 79 (2005): 693-707.

Broz, Lawrence J., and Richard S. Grossman. "Paying for Privilege: The Political Economy of Bank of England Charters, 1694-1844." Explorations in Economic History 41, no. 1 (2004): 48-72.

Calomiris, Charles W. "Price and Exchange Rate Determination during the Greenback Suspension." Oxford Economic Papers, New Series 40, no. 4 (1988): 719-50.

Calomiris, Charles W., and Stephen H. Haber. Fragile by Design. Princeton and Oxford: Princeton University Press, 2014. 


\section{Britain's First Experience with Paper Money}

Cannan, Edwin. The Paper Pound of 1797-1821. The Bullion Report 8th June 1810, New York, Kelley Reprints, 1969 [1919].

Chadha, Jagjit S., and Elisa Newby. "Midas, Transmuting All, into Paper: The Bank of England and the Banque de France during the Revolutionary and Napoleonic Wars.” Bank of Finland Research Discussion Papers 20-2013, 2013.

Chamley, Christophe "Interest Reductions in the Politico-Financial Nexus of EighteenthCentury England", The Journal of Economic History, 71, no. 3 (2011): 555589.

Chesney, Charles C. Waterloo Lectures: A Study of the Campaign of 1815. London: Longmans, Green and Company, 1868.

Clapham, John. The Bank of England. Cambridge: Cambridge University Press, 1944.

Clark, Gregory. "What Were the British Earnings and Prices Then? (New Series)." MeasuringWorth, 2014.

Cox, Gary, W. "Marketing Sovereign Promises: The English Model." Journal of Economic History 75, no. 1 (2015): 190-218.

Dasgupta, Aditya, and Daniel Ziblatt. "How Did Britain Democratize? Views from the Sovereign Bond Market.” Journal of Economic History 75, no. 1 (2015): 1-29.

Dickson, Peter, G. The Financial Revolution in England. London: Macmillan, 1967.

Feavearyear, Albert. The Pound Sterling. A History of English Money, 2nd ed. Oxford: Oxford University Press, 1963.

Fetter, Frank W. Development of British Monetary Orthodoxy 1797-1875. Cambridge: Harvard University Press, 1965.

Flandreau, Marc, and Kim Oosterlinck. "Was the Emergence of the International Gold Standard Expected? Melodramatic Evidence from Indian Government Securities." Journal of Monetary Economics 59, no. 7 (2012): 649-69.

Flinn, Michael W. "The Poor Employment Act of 1817.” Economic History Review 14, no. 1 (1961): 82-92.

Frenkel, Jacob, A. "The Forward Exchange Rate, Expectations, and the Demand for Money: The German Hyperinflation." American Economic Review 67, no. 4 (1977): 653-70.

Gayer, Arthur D., W. W. Rostow, and Anna J. Schwartz. The Growth and Fluctuation of the British Economy 1790-1850, 2 Volumes. Oxford: Oxford University Press, 1953.

Grellier, J. J. The Terms of All the Loans Which Have Been Raised for the Public Service. London: Richardson, 1812.

Guinnane, Timothy W., Harvey S. Rosen, and Kristen L. Willard. "Turning Points in the Civil War: Views from the Greenback Market." American Economic Review 86, no. 4 (1996): 1001-18.

Hoffman, Philip. "Prices, the Military Revolution, and Western Europe's Comparative Advantage in Violence." Economic History Review 64 (2011): 39-59.

Johnston, Neil. "The History of Parliamentary Franchise." Commons Library Research Paper 13/14, 2013.

Kindleberger, Charles P. A Financial History of Western Europe. London: Routledge, 1984.

- "British Financial Reconstruction, 1815-1822 and 1918-1925." In Comparative Political Economy. Cambridge, MA: The MIT Press, 2000. pp. 349-363. 
Lewis, Arthur W. Growth and Fluctuations 1870-1913. London: George Allen and Unwin, 1978.

Li, Ming-Hsun. The Great Recoinage of 1696-9. London: Weidenfeld and Nicolson, 1963.

Macaulay, Thomas B. The History of England, Vol. V, p. 2438. London: J. M. Dent and Sons LTD, 1914.

Meltzer, Allan, and Saranna Robinson. "Stability Under the Gold Standard in Practice." In Money, History, and International Finance: Essays in Honor of Anna J. Schwartz, edited by Michael D. Bordo. Chicago: University of Chicago Press, 1989.

Mignet, François, A. History of the French Revolution, from 1789 to 1814. London: Hunt and Clarke, 1826.

Mitchell, Brian, R. British Historical Statistics. Cambridge: Cambridge University Press, 1988.

Neal, Larry. The Rise of Financial Capitalism - International Capital Markets in the Age of Reason. Cambridge: Cambridge University Press, 1990.

_. "A Tale of Two Revolutions, International Capital Flows, 1789-1819." Bulletin of Economic Research 43, no. 1 (1991): 307-37.

North, Douglas C., and Barry R. Weingast. "Constitutions and Commitment: The Evolution of Institutions Governing Public Choice in Seventeenth Century England." Journal of Economic History 49 no. 4 (1989): 803-32.

O'Brien, Patrick K. "The Political Economy of British Taxation, 1660-1815.” Economic History Review 41, no. 1 (1988): 1-32.

_. "The Triumph and Denouement of the British Fiscal State: Taxation for the Wars against Revolutionary and Napoleonic France." London: London School of Economics and Political Science Working Paper No. 99/07, 2007.

- "Mercantilist Institutions for a First but Precocious Industrial Revolution." London: London School of Economics and Political Science Working Paper No. 156/10, 2010.

Officer, Lawrence H., and Samuel H. Williamson. "History of Forward Contracts (Historical Evidence for Forward Contracts)." The New Palgrave Dictionary of Economics, Online Edition, edited by Steven N. Durlauf and Lawrence E. Blume. Palgrave Macmillan, 2009.

_. "Measuring Worth." 2013.

Oosterlinck, Kim "Reparations", The New Palgrave Dictionary of Economics, Online Edition, eds. Steven N. Durlauf and Lawrence E. Blume, Palgrave Macmillan

Oosterlinck, Kim, Loredana Ureche-Rangau, and Jacques-Marie Vaslin. "Baring, Wellington and the Resurrection of French Public Finances Following Waterloo." Journal of Economic History 74, no. 4 (2014): 1072-102.

Perron, Pierre. "The Great Crash, the Oil Price Shock and the Unit Root Hypothesis." Econometrica 57, no. 6 (1989): 1361-401.

Redish, Angela. "The Evolution of the Gold Standard in England." Journal of Economic History 50, no. 4 (1990): 789-805.

Ricardo, David. The Principles of Political Economy. In P. Sraffa (1956) ed. Vol. I., 1817.

Rostow, W. W. British Economy of the Nineteenth Century. Oxford: Clarendon Press, 1948. 


\section{Britain's First Experience with Paper Money 1077}

Sargent, Thomas J., and François R. Velde. "Macroeconomic Features of the French Revolution." Journal of Political Economy 103, no. 3 (1995): 474-518.

. The Big Problem of Small Change. Princeton: Princeton University Press, 2002. Schumpeter, Elisabeth Boody. "English Prices and Public Finance, 1600-1822." The Review of Economics and Statistics, 20, no. 1 (1938): 21-37.

Stasavage, David. "Partisan Politics and Public Debt: The Importance of the "Whig Supremacy' for Britain's Financial Revolution.” European Review of Economic History 11 (2007): 123-53.

Sussman, Nathan, and Yishay Yafeh. "Institutional Reforms, Financial Development and Sovereign Debt: Britain 1690-1790." Journal of Economic History 66, no. 4 (2006): 906-35.

Tooke, Thomas. Thoughts and Details on the High and Low Prices of the Last Thirty Years, 2nd edition. London: John Murray, 1824.

Webb, Steven B. "Fiscal News and Inflationary Expectations in Germany after World War I." Journal of Economic History 46, no. 3 (1986): 769-94.

White, Eugene N. "Making the French Pay: The Costs and Consequences of the Napoleonic Reparations.” European Review of Economic History 5, no. 3 (2001): 337-65.

\section{HISTORICAL SOURCES}

Bank of England Archives, items 10A270/1 and 10A321/1.

Hansard 1807, 1808, 1819.

London Gazette 1802, 1805, 1807, 1813, 1814, 1815.

London Times 1800, 1802, 1805, 1806, 1807, 1808, 1811, 1812, 1813, 1815, 1816, 1821.

Report from the Secret Committee on the Expediency of the Bank Resuming Cash Payments (Parliamentary Papers, 1819).

Report by the Secretary and Comptroller General of the Proceedings of the Commissioners for the Reduction of the National Debt (Parliamentary Papers, 1891). 